\title{
The Aboriginal people in Sydney as seen by Eugène Delessert, December 1844 to August 1845
}

\author{
Colin Dyer
}

Eugène Delessert was born in Le Havre, a sea-port in northern France, in 1819. He was thus only 25 years of age when he arrived in Sydney in late December 1844.

His journal of this voyage, under the full title Voyages dans les deux océans Atlantique et Pacifique, 1844 à 1847, Brésil, Etats-Unis, Cap de Bonne-Espérance, Nouvelle-Hollande, Nouvelle-Zélande, Taïti, Philippines, Chine, Java, Indes Orientales, Egypte (326 pp), was published in Paris by A Franck, Libraire, 69 rue Richelieu, in 1848. On page 51 of this volume he says, when crossing the Equator on 19 October 1844, that he was 'recrossing this for the fifth time'. He was thus already a well-seasoned traveller, although this was his first visit to Australia.

In August 1844 he had set out from Le Havre for Australia and, on this occasion, would be away for some three years before returning home.

His journey to Australia began with a short stay in London before setting sail in The Persian from Portsmouth, on England's south coast, on 17 September. After travelling via the Cape of Good Hope, The Persian arrived off the north coast of Tasmania on 20 December but, due to unfavourable winds, was forced to sail around the island before arriving safe and sound in Sydney Harbour on 27 December. The journey from Portsmouth had thus been accomplished in just three months and ten days.

In the Introduction to his journal Delessert declares that he was 'always careful to keep an exact record' of events during his travels and, in the section presented here, says that 'among all my compatriots who have written about NewHolland, none has stayed here as long as I have', and, he continues, 'I dare to say, what I write about them [ie the New-Hollanders] is without exaggeration or prejudice'. Joseph Fowles, in his Sydney in 1848, published shortly after Delessert's visit, echoed these sentiments. Delessert, he declared, was 'one of the foreign gentlemen to visit the Colony who may be fairly considered to have written without prejudice or bias', and had 'enjoyed the best opportunities of becoming acquainted with the state of society amongst us'. ${ }^{1}$

1 Fowles 1848: 27-28. 
Six years after leaving Australia (in 1851) Delessert was in California where he was a member of San Francisco's Vigilance Committee, formed by bankers and other leading citizens to combat the rampant lawlessness reigning there. He was indeed listed in San Francisco's 1852-3 city directory as a resident banker with Delessert, Cordier and Company. Later in the 1950s he returned to reside in France, and then in Algeria where he died at Médéa in 1877.

$* * *$

Delessert stayed in Sydney for nearly eight months (departing on 15 August 1845), and it is the part of his journal describing the Aboriginal people (pages 127 to 151 of his original French) that is translated.

\section{Translation of Delessert's text, pp 127-151}

In certain tribes, the men are in the habit of covering their forehead with a white or red bandage. This custom - which is especially difficult to explain for those with short hair - is no doubt linked to some superstitious idea. They usually grow their hair very long, and often knot it on top of their head. Indeed, they have no other hairstyle. Pierced ears complete the portrait of the Aborigines of Australia, ${ }^{2}$ whose colour is less black than the negroes [nègres] of Africa...

Women's clothing consists of a simple kangaroo skin, which they call 'wo-rwan'. When approaching town, or when the weather is bad, they drape a sort of mantle over their bodies, which comes down to their knees. A sack hanging from their shoulder, which is called a 'kin nun', serves as a recipient for the food they pick along the way. Those who have a child sometimes add to this accoutrement a short of plait to cover it and protect it from the cold. They wear no ornament but, exceptionally, the girls intertwine some flowers in their frizzy hair. They too have their 'coquetterie', and one could say they use make-up; but what makeup! A piece of wood charcoal reduced to powder, and with which they crudely smear their forehead and cheeks!

The men and women also rub their bodies with a sort of red earth mixed with grease, which makes them give off the most unpleasant smell. They use this process in order to maintain the 'cleanliness' of the body and to protect themselves from the effects of the rain and the sun. As a sign of mourning, the men paint across their forehead a band of white colour which goes down as far as their cheekbones. For the women, this white band is replaced by broad patches of the same colour. If it is a relation they have lost, their grief is manifested by deep incisions which they make on their bodies and which they leave wide open. I have seen old women whose blood ran along their temples as a consequence of a demonstration of this kind and made in the same circumstances.

2 Delessert thus uses both the terms 'Australia' ('Australie' in the French) and 'Nouvelle-Hollande'. In his The Life of Matthew Flinders, Ernest Scott observes that 'the nineteenth century was well within its second quarter before the name New Holland gave place ... to the more convenient and euphonious designation: Australia', Scott 1914: 1. 
It is not a sign of war that the natives here paint their bodies, as in other parts of New South Wales. They reserve this kind of ornament for their dance meetings. There they can be seen striped with red or white bands which go from their neck down to their feet. To these they add transversal lines which they trace on their chest and tummy, which gives them a quite diabolical appearance. They tattoo themselves, but in a rather crude manner. This operation, such as they see it, consists of making deep cuts, mainly on the chest and shoulders, and then maintaining there a prominent scar. The resulting impressions are considered both as marks of personal distinction and as a means of recognition of each tribe.

Although the horrible custom which makes these natives cannibals has been abolished around inhabited areas, it is probable that this still exists among the natives in the interior. I remember an elderly native whom I once questioned on this subject, an extremely gentle man who had nothing ferocious about him, telling me he had eaten human flesh when a child; he also added that he could make up his mind to begin again today. It is true that he lived near Sydney, where he had become just a bit civilised. The traveller Cunningham was one day at the farm of one of his friends, forty miles from Sydney, when one of the tribes from Argyle stopped there. It had just been fighting tribes from Bathurst which had erupted onto its territory. Cunningham asked one of the warriors how many people he had killed, and the man raised five fingers thus designating the number he had slain. A woman was among these, and the warrior showed him a few left-over bits of her which he promised himself he would devour as he had done the rest. It is curious to note that this barbaric custom only exists among people who have no elected or hereditary chief, or who recognise no other superiority than that of force and individual bravery.

The natives live entirely in the woods, but they build no hut of any kind there. A make-shift shelter suffices. With a few branches stuck in the ground up against a tree or rock, they make a kind of arbour where they have just enough room to squat.

In the rainy season they cover it with bark, and place stones on this fragile roof so the wind will not carry it away. They usually take care to choose the most sheltered spots for these crude huts, and set them up in situations opposed to the prevailing winds. They maintain fires day and night of which, they say, the smoke drives away the mosquitoes.

When they travel or make only short distances from their camp, they take a stick burning at one end in order to make a fire whenever needed. They all carry one in winter, under their kangaroo skins [sous leur peau de kanguroo], to help keep the cold out. This stick too, according to their beliefs, should protect them against the spirit of darkness of which they have great fear.

One can easily see in the woods the spot where the negroes [nègres] have slept because of their custom of burning two small fires between which they sleep with confidence, protected, as they believe, by the demon of the night, which they call 'Potoyan'. 
The nomadic life of the Aborigines [aborigènes] of New-Holland is probably one of the causes of the stupidity of their nature. It is perhaps also why they do not seek to make utensils they could not take with the light baggage required by their frequent passage from one place to another. Mr Cunningham contrasts these savage peoples [ces peuplades sauvages] with the New-Zealanders who, for their part, are obliged to set up a fixed residence amongst their yams, their sweet potatoes and the animals they raise, because the woods do not provide enough game for their food. They decorate their huts with sculptured dishes and other objects which they prepare in their leisure time, and which they are happy to show.

Perpetual wars, the destruction of children etc. are obstacles to population growth. Necessity never requires them to come together and to provide for their needs by artificial means, like most natives in the southern islands of Polynesia. The Australians who live under roofs [sous les toits] are generally those who inhabit certain parts of the coast, where shellfish and fish assure their food supplies for a large part of the year.

Amongst a people who are not very industrious, and who easily do without objects which seem the most necessary to life, one must not expect to find weapons very remarkable for their elegance or ornamentation. Consequently the weapons of the New-Holland natives cannot bear comparison with those masterpieces of patience that one sees in the hands of the Aborigines of NewZealand, Fiji, Tahiti, etc. It is not without trouble and sacrifice that I managed to obtain most of the weapons in use among the savages [sauvages] of the interior of New-Holland; they do not wish to part with them either for money or in exchange for anything.

As soon as I had obtained one of these weapons, I sought to discover its name and use. The plate that I have had engraved gives an exact idea of the shape of these various weapons. It will be easily understood that, not being made according to a model as in Europe, each one of these weapons presents differences which depend upon the whim of he who makes it, upon the nature of the wood at his disposal, and upon the shape of the accessories he uses.

The lance, called the 'mo-ting', is usually employed for fishing. At one end it has four prongs whose extremities are fitted with sharpened kangaroo bones. These prongs may be brought closer together or further apart by using the little crosspieces fixed against the cord, which ties the prongs to the lance. The lance itself is about eight feet long. At the other end there is an indentation into which fits the hook on a stick called the 'wom-mur-rur', which helps to throw the 'mo-ting'. I have often witnessed the skill with which they harpoon fish several feet under water and which I could hardly see.

The 'ta-win' is a club made of very hard wood, about a foot and a half long. On each side, large pieces of sharp silex are fixed which create a double edge (and 
take the place of iron, the use of which is known only a short distance from the sea). The pieces of silex are attached with hard and resistant resin. This very primitive weapon is today only used by tribes in the interior.

The 'wa-rai' is a lance made of light wood with a piece of iron or silex at the end. The same name is given to a weapon made of iron-wood, and armed with either kangaroo teeth, pieces of silex, or hooks. These javelins, which the natives throw great distances without using the 'wom-mur-rur', are five to six feet long.

The 'mogo' or 'bai-bai' is a sort of axe consisting of a sharpened stone held by a shaft of braided cane. Again, this is one of those primitive instruments no longer seen near places occupied by Europeans.

The 'waddy' and the 'nulla-nulla' are the most common weapons. They are all small clubs. The waddy is quite long; the nulla-nulla is made of ebony and has one end which is heavy, rounded and carved. The Indigenous people [indigènes] rarely walk about without carrying one or the other of these weapons, and use them to settle their various disputes. When this occurs, each of the combatants lowers his head in turn to receive his adversary's blow, until one of them falls down. Avoiding a blow is considered cowardly.

Other weapons of various shapes and sizes are to be seen, and are always made of wood and more or less carved. The ones the natives call 'mal-ga' are headbreakers. One has a long sharpened point at right angles to the shaft which is straight; the other, whose shaft is somewhat curved, forms two sharp angles. These are terrible weapons in the hands of the natives, and it is all the more difficult to protect oneself from them because one cannot see whether the blow will come from the point or the back of the instrument.

The 'muri-muri' takes the place of the knife and, like the ta-win, is made of blades and silex set in hard and non-flaky resin. It seems that bows and arrows are not known in New-Holland; at least I have never seen any, and I do not think they have ever been mentioned in any travellers' accounts.

The Aborigines have two kinds of shields or 'koreils'. One is narrow, thick and triangular, and just over two feet long, and they use it very skilfully by whirling it around. The other is oval-shaped, and protects the carrier against blows from lances or javelins. These shields are usually carefully sculpted, and daubed with red and white colours.

The most remarkable weapon by far is the boomerang [boomereng], called 'turra-ma' by the Aborigines.

It is a projectile made of a piece of very hard wood, about two feet two inches long and slightly curved. It weighs about 9 to $91 / 2$ ounces. One side is slightly convex and clad with inlaid ornamentation, while the other is flat and smooth. When ready to be thrown the boomerang is held horizontally and, as a rotation movement is imparted to it when thrown, the air presents so much resistance to the flat side and so little to the convex and cutting edge while it cleaves through 
the air, that on its long journey it does not seem to submit to the usual effects of gravitation. This weapon, so simple and strange, would pose complicated problems to learned people who would like to explain why, when thrown to the right, it comes back at two or three hundred paces to the left; and why, after having been thrown out of sight and as far as gunshot, it comes back after cleaving the air for several minutes [sic] to fall at the feet of him who threw it.

The use of the boomerang requires lengthy practice. I have often tried, but have never managed to throw it further than any ordinary stick. The Aborigines do the most surprising things with it. If they wish to kill an enemy two or three hundred paces away they successively throw one or two boomerangs, one to the right and the other to the left, and the unfortunate fellow who is their target rarely escapes this terrible projectile. If the first weapon misses him, the second inevitably hits him. One can only dodge these by using great skill, and a very special shield.

There are two kinds of boomerang. One is less long and more curved, and comes back to the thrower's feet. The other does not come back, but travels further. In his book on New South Wales, Major Mitchell says one can achieve incredible feats with this weapon, as for example, sending it over the top of a tree to hit something behind it... ${ }^{3}$ When cast amidst a flock of wild ducks it creates the most frightful carnage, and it is used mainly for this ... It can skim just above the ground or rise to great heights, according to the wish of the thrower.

With the first lance I have described the Aborigines skilfully spear fish which they seek for food, and which they often eat raw straight from the water. The end of the 'wom-mur-rur', which is flat and slightly sharpened, is used for digging up various roots, as well as the larvae of ants' nests, of which they are very fond. They also eat every sort of lizard and snake, even those which are known to be the most poisonous. They take care, however, to gut them and cut off their heads. Although snakes are very numerous in New-Holland, I have only encountered but one during my eight-month stay in Sydney and yet I made long and frequent excursions in the woods. When that snake appeared before me, I killed it with a rifle shot, and was preparing to mutilate it more but the native accompanying me cried 'Tan-to-a! Tan-to-a! Yano-a wwa yi-kora!' (Stop! Stop! Don't do that!) So he took it and, after cutting its head off to be sure it was dead, he used it like a cravat while waiting to eat it for supper. Just like hungry dogs, the natives feed themselves, when hunger presses them, on everything which comes to hand, so it is not rare to see them in the streets searching amidst the rubbish and grabbing pieces of raw meat already in a state of putrefaction.

Major Mitchell tells how one evening, after setting up camp where he and his companions were peacefully asleep, he was attacked by the Indigenous people [les indigènes] who wanted to get hold of their baggage. When these people had been repelled, the travellers picked up, the next morning, a bag (kin-nun) that

3 Delessert is referring to Major Mitchell's Three Expeditions into the Interior of Eastern Australia ..., Mitchell 1839, vol II: 348-349. 
an individual in his flight had left behind a tree, in which they found a sample of the daily food of these savages [sauvages]: three snakes (mot-tos), three waterrats (pur-ra-moi-ban), about two pounds of small fish (bir-ra-ba), a quantity of roots, etc. The same bag even contained a few cutting stones (puk-kor) and two hatchets (ma-go) like the one I have described above. ${ }^{4}$

It is curious to see an Aborigine pursue a possum (wil-lai) when this animal has taken refuge in the hollow of a tree. As soon as the hunter has recognised, on the tree-trunk indicated to him by his dog, the marks of the possum's claws, he climbs up it by means of a rather ingenious method consisting of making on the wood, as he goes up, notches or cuts with an axe. Each cut, quite deep, helps him successively to place his big toe, and to cling on until the top of the tree. While the hunter is making a cut, his whole body thus remains supported by his big toe. These men, moreover, make use of their feet with as much dexterity as their hands, and it is with their feet that they pull out of the water a species of shellfish (unio) which they eat.

If they surreptitiously sneak something it is almost always with their feet, and they take advantage of their thick hair to hide in it quite often the object they have stolen. With their feet they also throw dust and even stones at their enemies.

As a consequence of this habit, contracted since their youth, to climb trees, their big toes - on which all the weight of their bodies is borne in this exercise acquire over time an extraordinary strength. It is a frightening spectacle to see them, when they climb to the top of a tree, holding on with just one hand, cut with an axe with the other, and arrive at heights of more than a hundred feet on very large and straight trees with smooth bark. As their song says it so well:

'Morruda yerraba tundy kin arra

Morruda yerraba min yin guiny wite mala.'

(On the tracks the white man walks with shoes which crunch, but he cannot climb trees, nor make use of his fingers.)

When the hunter arrives near the cavity in which he supposes the possum has taken refuge, he plunges a long stick into it, and thus makes sure the animal is there. If he cannot catch it with his hand, he then makes an opening just below the hole containing the possum, probes again to force it to hide its head in it by hitting it strongly several times against the trunk of the tree.

The natives of New-Holland have senses which are as fine and developed as those of the dog. The slightest noise alerts their attention, and they can follow the trace of a man's footsteps on all kinds of terrain, so long as they are fairly recent and the ground has not been made wet by rain. They can also work out very precisely how long it is since the individual went by, and can even tell if the footprint is that of a black or a white man. The police use these natives to seek our Bushs-rangers [sic] (convicts on the run), and rarely fail to find them.

4 Mitchell 1839, vol II: 270. 
The dark colour of their skin enables them to keep out of sight more easily than a white man, and thus they have greater facility for killing a kangaroo, which they call 'mo-a-ne'. With great skill they can find parrots' nests, whose eggs they eat. As for these birds' little ones, they raise them to sell them in the towns and this, it seems, is the only industry in which they indulge. It often happens that an Aborigine will cover twenty leagues (about eighty kilometres) to sell a parakeet for some feeble sum of money, soon dissipated on drink and hard liquor. They employ a rather curious trick to hunt the New-Holland emu or cassowary.

This bird, whose shape reminds one of the ostrich, is very shy, and runs with great speed. In order not to frighten it, hunters take care to cover their bodies with branches and, concealed by their shields (equally covered with foliage), they get up close enough to the emu to be able to throw a long javelin at it. For hunting they usually use a lance made of light wood and ending in a stick made with a species of very hard cane. They sometimes use the stalks of the Xanthorrhea.

When they wish to prepare the flesh of the kangaroo for food, they begin by digging a fairly deep hole in the ground, and light a big fire in it. They then throw in a quantity of stones, and leave them there until they are very hot. Then they empty the hole, clean it, and place there - without even skinning it - the kangaroo which they intend to roast and which they cover with heated stones. This operation suffices for they do not wait until it is well cooked before eating this animal.

Some of their superstitious ideas are related to the individual's food. According to them, each age group and gender must have its own type of food. Thus, after eleven or twelve years of age, the girls no longer eat a kind of animal they call 'bandicouts' [sic], these dishes being capable of harming their approaching fecundity; and, should the boys ever eat black eagle, they would never see their faces adorned with a beautiful beard. It is only after thirty that one can use kangaroo flesh, and before that age they do not wish to taste emu because then, they say, their skin would cover with pimples.

It often happens, in certain parts of New South Wales, that water sources dry up and, as a result of hot weather or a long drought, water is completely lacking. How then we must pity the Aborigines who, when all the little streams are dry, are obliged to cover several leagues haphazardly without knowing which way to go, in order to quench their devouring thirst!

The circumstance adds to the difficulties of an expedition to the interior. Major Mitchell and Dr [sic] Cunningham were forced more than once, during their excursions, to go without water for several days. One often hears settlers say that they can only obtain water by travelling distances from four to five miles away. The Sydney newspapers in August 1847 announce that Dr Leichardt [sic], the intrepid traveller who discovered the overland route between Botany Bay and Port Essington, has failed in his new enterprise to cross New-Holland from east to west at its widest part, and that it is lack of water which forced him to 
retrace his footsteps after a month of travel, to the great disappointment of the whole colony, where all minds are preoccupied by the idea of colonising the interior of the country. ${ }^{5}$

I have sometimes suffered myself from this lack of water, which hunting made even more tiresome during a whole day in the great heat. Not finding the smallest stream, I was obliged to make do with the muddy liquid lingering in the ditches under deep shady places.

This water shortage was so bad in 1827, where for six months not a drop of rain fell, that the police seized the inhabitants' wells and water-tanks in order to regulate water rations distributed daily. Nowadays, as a consequence of measures taken by the administration, and which required long-term works, water arrives in Sydney from different places. ${ }^{6}$ In the countryside, some farmers dig wide dams or reservoirs to collect the rainwater, which they take care to clarify with a filter.

The Aborigines seem to have no idea of religion and, to my knowledge, no-one has anywhere found anything resembling an idol. On the other hand, they are not foreign to all kinds of superstitions. Thus they believe in the influence of dreams, in charms and magic spells, and they attribute almost all their illness or misfortunes to bad spirits to which they give different names. They believe that those who die go to another country, are there transformed into white men, and come back later to live in their land. This doctrine, however little developed it may be (and which reminds one of metempsychosis), is engraved so deeply in their imagination that, every time they think they see a sort of resemblance between a white man and one of their deceased friends, they are absolutely convinced of the identity of the two people.

Some of their most singular customs, and I will even say the most barbaric, could scarcely be interpreted other than as sacrifices they intend to offer to their bad spirits. When a young man, for example, arrives at the age of puberty, it is necessary according to them, in order that he becomes completely a man, that he allows the second incisor tooth from the left side of the upper jaw to be extracted. In other parts of Australia, this operation is only complete when two teeth have been removed instead of one.

A few days before the ceremony, the victim withdraws to the interior of the woods, where he imposes upon himself a sort of starvation diet, and avoids showing himself in front of any human being. After a few more or less bizarre preparations, they proceed to sacrifice the tooth. This is not positively pulled out, but a man, whom they call 'Coradji' or 'Karakul', knocks it out with a wooden

5 Friedrich Leichhardt's expedition reached Port Essington in December 1845 after completing an overland journey of some 3,000 miles. His attempt to cross Australia from east to west failed when he was forced, after covering only 500 miles, to return in June 1847. He disappeared, while making a second attempt, in April 1848.

6 Delessert is doubtless thinking of Bushy's bore, a project to convey water in cast-iron pipes 'from the large lagoon near the old paper mill, south of the South Head-road to a reservoir to be formed in Hyde Park'. This was begun in September 1827 and not completed until June 1837. 
awl which he applies to the tooth and a stone used as a hammer. All this is done with three sharp measured blows. Henceforth the young man, designated until then under the name of 'ko-ro-mun', becomes a 'Yiraba'. The ceremony is called 'Kua-lung', or rather 'Kumun-billi-kotira', which means literally 'to take out the tooth'. Once a young man has undergone this ordeal, he has the right to take a wife, ${ }^{7}$ to arm himself with a lance and a shield, and to participate in his tribe's combats. He then no longer needs to fear an encounter with 'Put-ti-kan', which is how they name the evil spirit which kills all those who have not undergone the tooth operation.

It is rather difficult to explain another extraordinary custom, which consists of cutting off the women's little finger of the left hand, or more exactly its two last phalanges. Some travellers, trying to find a reason for this, had thought at first that certain women acquired a particular right [un droit particulier] by this means; but it was noticed that married women and girls had been thus mutilated, which makes this explanation very doubtful. Others imagined that the women were able, by means of this amputation, to wind their fishing-lines more easily around their hand - a supposition which, in my opinion, does not give a better reason for this strange custom.

When one of their people has been killed, the tribe to which he belonged gets together immediately and swears, in the presence of the dead body, to avenge his death; but it is all the same to them whether they kill the principal guilty person or another man of an opposing tribe. The law of 'an eye for an eye' is quite wide-spread among them, and even has a rather far-fetched interpretation. If, for example, a man perishes accidentally, either by falling from a tree or perhaps by diving into the sea or from any other means, his friends impute his death to some evil spell from an enemy tribe... When an individual is seriously unwell and fears succumbing to his illness, he finds no other way to escape the danger threatening him than to put to death, if he can, just anyone.

I have already spoken about the sentiment which brings them after the death of a relative (and to testify to their deep affliction) to injure themselves with cutting instruments, and even with burns strong enough to hinder their ability to walk. The cause of this custom is unknown, unless it be their belief in demons. I have often asked some of them why they had allowed themselves to be mutilated, to have their teeth removed, to be burnt, tattooed, etc. They replied simply: 'My father did it, my grandfather too, and my children will as well, I hope.'

Polygamy is generally admitted among these people, each man being able to possess a certain number of women of any age. There exists another rather singular custom among them, whereby a man is allowed to court a woman while her husband is still alive, provided the two spouses give their consent, and with the proviso that the 'sigisbée' ${ }^{8}$ shall marry the woman after her husband's death. The latter then receives some gifts as well as his female companion. When a

7 Une femme means both 'a wife' and 'a woman'.

8 In Italian a cicisbeo is the more or less recognised gallant of a married woman. 
man dies, custom has it that his women withdraw into their fathers' tribe during the mourning period. There, they live almost disdained by those very people to whom they should belong, and would incur an exemplary punishment if they went back to them straight away.

When a woman gives birth to twins, one of them is put to death and, if they are of different gender, it is the male who is then sacrificed. The reason these savages [ces sauvages] fall into such barbarity is that a woman cannot have enough milk to feed two children at once, and she also would not be able to seek enough food for them and herself at the same time. Mothers suckle their children until they are four or five years old but, well before weaning, they already teach them how to procure part of their food.

As it is customary among the Australians [Australiens] to take their wives from foreign tribes, he who wishes to have a companion - or, rather, a slave - sets out secretly at night with a few of his comrades and, club or 'waddy' in hand, they all throw themselves upon the parents of the girl, whom they surprise in the midst of their sleep. For his part, the lover grabs her who has been the object of his preferences and takes her off with him to his tribe, not without having first overwhelmed her with blows and bad treatment, and almost always unconscious.

This last trait, which is difficult to believe since nothing explains it, is reported by a few travellers, among whom George Barrington in his Voyage to New South Wales. 'As soon as one of these natives [naturels]', he says, 'has caught and abducted the woman he has chosen and whom he goes to seek in an enemy tribe, he knocks her over, hits her with a club on the head, the back, etc. and, seizing her by one of her arms, he drags her, streaming with blood, through the woods, over rocks and mountains with all the violence and determination of a savage [barbare] till he finally reaches his companions. The tribe to which the woman belonged usually seeks revenge for this outrage by the law of "an eye for an eye" [la loi du talion], but the wife holds no grudge and rarely abandons her husband and her new tribe. ${ }^{\prime 9}$

The fact of these nocturnal abductions has been confirmed to me by a native who had attended, in his youth, one of these expeditions.

The women in this country are not better treated than beasts of burden, and their life is but a series of misery and slavery. One sees them, carrying their children on their shoulders and hips, laden additionally with a heavy bag containing provisions and fishing instruments. They cross woods and marshes, and are often obliged to scramble up the sand-dunes beside their master, who is free from all the burden and has only the trouble of carrying his light weapons in his

9 This is in fact from George Barrington's 1802 The History of New South Wales (Barrington 1802: 35). In 1802 Pierre Milius (with Baudin's expedition) had written: 'A very polite way of courting a lady [une dame] in New Holland is to bash her with a club ... Such a treatment makes the women very faithful to their husbands.' Milius 1987: 48. 
hands. It is also the women who go in search of food, plunging at times into the depths of the rivers to pull out shellfish which they cook under hot coals, and at others pursuing possums to the top of the highest trees.

In our countries, where civilisation has shown itself justly generous towards women, these latter, young and beautiful, hasten to enjoy the power which the years will come only too soon to weaken. In Australia, to the contrary, fatal wrinkles and even decrepitude become titles to the empire that women exert over their compatriots. In fact, they make up half the important assembly [aréopage] which, in each tribe, deliberates upon public matters and punishes misdeeds indicated to them. This assembly is extremely jealous of its attributions, and carefully maintains all the most superstitious traditions and customs.

Even during war-time the most intrepid chiefs bow their head before these elderly matrons, and receive from their hand, without a murmur, blows from a club, hoping that such an abject attitude will conciliate their favour and good will, and thus ensure they will smoke their skin [sic] if they should perish in the fray.

Among the Australian peoples who live furthest from the sea and the rivers, and thus suffer more often from food shortages, the women are called upon to fulfil yet another function. When famine devastates the land it is they who point out the victims who, sacrificed to the bad spirit, must be put to death during their sleep and serve as food for their famished companions. These horrible sacrifices appear to be in use in almost all the islands of Polynesia.

The old men also have some personal prerogatives. Emus' eggs, their flesh and that of the kangaroo are exclusively reserved for them, and young people do not touch these delicate dishes. It is the old men too who, in war-time, give the orders and the signal to throw boomerangs or other such weapons.

The dances in which they indulge have retained, for the most part, a quite savage energy and vivacity. They usually take place in the light of burning torches and to the sound of a sort of tambourine made with a possum skin or bladder, stretched over a wooden hoop. The chants which accompany this have a remarkable cadence, at times slow and soft, and at others strong and animated, having some resemblance to the humming of a bee and the howls of numerous animals.

The figures of their dances are very varied, but above all they have a very bizarre form of entertainment, of which I can give here only a very imperfect idea. Two of the most skilful participants (and recognised as such by the assembly) open the dance which, at first gentle and moderate, gradually takes on a more lively character, the other actors joining in successively to play their part. After a while, only one individual is left behind, and it is then that a general ballet begins in which everyone, following a certain rhythm, gives himself up to the most uncoordinated contortions and movements. Legs do the splits, heads quickly turn right and left, eyes burn bright, hands brandish all kinds of weapons, thus 
simulating the hunting and slaughter of certain animals. Then, at the moment when this exercise has arrived at its highest point of animation, everything becomes immobile and stops as if by enchantment.

The sight of all these naked men, with their bodies marked by a certain number of white and red stripes, produces in this light the strangest effect. The substance used to paint these ornaments, which the savages have the art of varying in such a way that not one looks like another, is fabricated by the natives themselves. It is a kind of earth they call 'ko-pur-ra' which they soak with water and which they mix, after cooking it, with kangaroo grease.

The dance I have just described, called the 'corrobory' [sic], seems to produce an extraordinary excitement on those who execute it. However indifferent or relaxed one of these savages may be, or even half asleep, should he decide to dance a 'corrobory' [sic] he immediately experiences its influences and develops, as this goes on, a supernatural energy and vigour. His muscles swell and stiffen, his ardour knows no limits. However, once this is finished, he regains his usual bearing and falls again into that state of inertia and laziness from which the dance managed to drag him for but an instant. I have seen some of them devote themselves for several hours to these horribly tiring games, and I could not understand how they could tolerate the fatigue for so long.

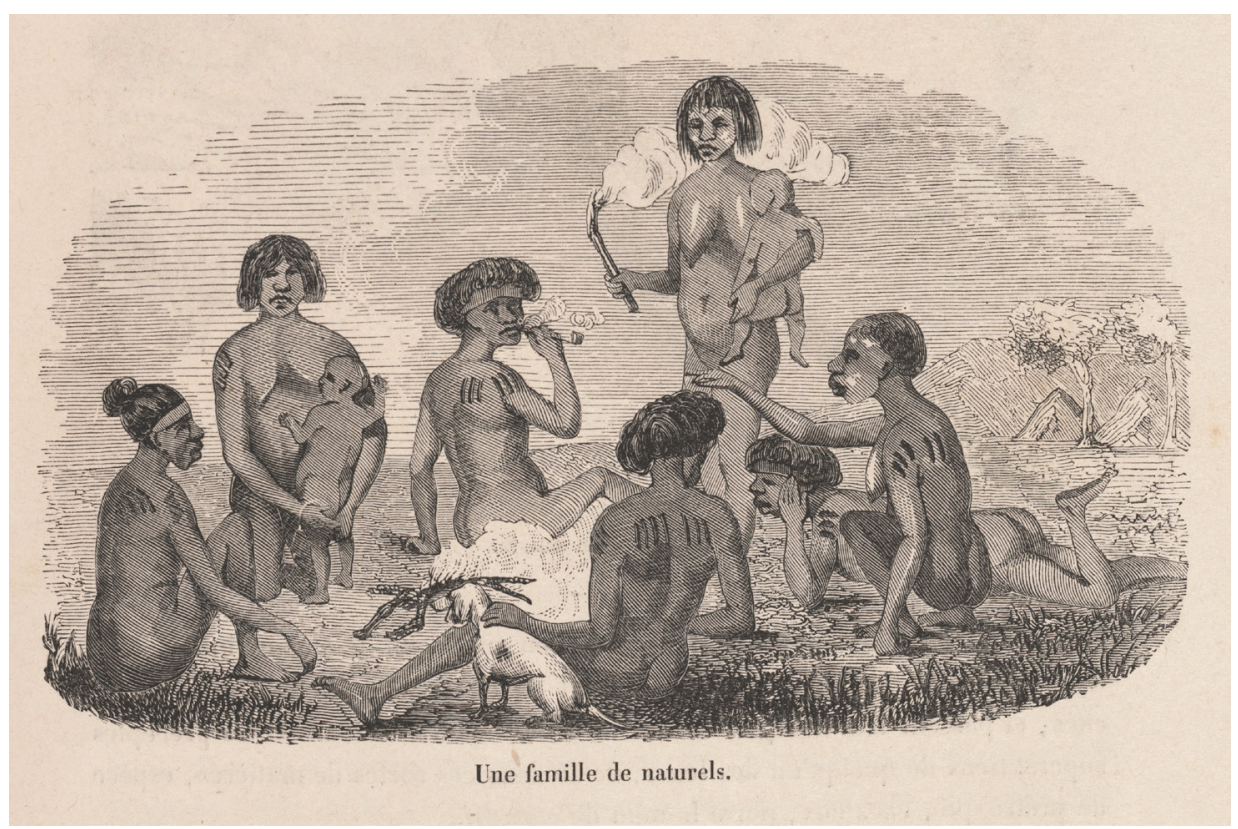

Une famille de naturels. 
A camp is rarely composed of more than six to eight huts, housing twenty to twenty-five individuals, men, women and children, always followed by a large number of dogs of all kinds. These animals, reduced to seeking their own food, are extremely skinny and covered in disgusting pustules [lèpres] which they can transmit to the individuals with whom they live. Their offspring are looked after by the women, who do not disdain on occasion to suckle them themselves. These dogs, who take up the best spots in the huts and are willingly used as pillows by the blacks [noirs], are gifted with the finest sense of smell which far surpasses that of our European dogs. They thus render great service to their masters by the speed with which they discover the track of certain animals.

The natives ordinarily light a fire in front of each hut. During the day they often eat together, semi-recumbent, and spend their time chatting or listening to the superstitious precepts of one of their companions versed in these matters, a sort of priest whom they call 'coradji'.

It would seem straightforward to us that individuals belonging, if not to the same family at least to the same tribe, would take pleasure in sharing their provisions and taking their food together. But it is quite otherwise among these populations, who often experience difficulty in procuring food, and where the fear of lacking it makes them egoistic and quick to take offence. As a consequence, the men are very jealous of their foodstuffs, which they eat in secret. However, should they be in the presence of others, they usually offer them a small portion.

Major Mitchell, whom I had the occasion to see in Sydney, has published the story of his exploration into the interior of Australia. His work presents very interesting details of his relations with the natives, who were then still unfamiliar with white people. They manifested great fear when seeing sheep, and the presence of a horse frightened them enough that they dared not attack the strangers. Beware, he, however, who should wander alone among these savage peoples [ces peuplades sauvages]! Looking upon the whites as veritable sorcerers, able to tame ferocious animals and carrying thunder about with them (for our weapons of war had the effect of thunder upon them), the Indigenous people [les indigènes] would have killed them just to make sure they were susceptible of dying. All this happened in 1836. ${ }^{10}$ Today a European could travel five hundred leagues in the interior without fear of being attacked by the Indigenous peoples, for they bear no ill-will towards the whites who know how to take them with gentleness. Unfortunately, from time to time disturbances occur in the interior which cause the death of some individuals, generally when sheep (which the natives no longer fear) are being stolen, and of which they are guilty.

One can understand that men, reduced to such an abject situation and forced to obtain food by every means possible, experience temptation at the sight of a large flock of sheep, and the desire gets hold of them to seize a few of these animals.

10 Delessert is referring to Mitchell's 'Expedition to the Rivers Darling and Murray' in Mitchell 1839, vol II. 
But this is often punished by a rifle shot, for the whites put no store on the life of these miserable beings [ces êtres misérables]. I am far from approving such brutality towards creatures who, after all, are men. I also do not approve of the whites needlessly killing kangaroos when they come upon them, just for their skins, when they know very well that these animals, unique to New-Holland, form a major part of the Aborigines' food [la nourriture des aborigènes]. A native said on this subject some years ago: 'Wite [sic] fellow come come, kangaroo all gone'. ${ }^{11}$

The new laws are excessively severe in this regard, and punish by death the white person [le blanc] who has intentionally killed a black person [un noir].

One could have thought that the Indigenous people belonging to the tribes of New South Wales, driven one day by cupidity and need, would spread out in great numbers among the towns and habitations in order to thieve and beg. Nothing, till now, has happened to justify this prediction. It is rare to meet in Sydney more than twenty or thirty Aborigines at one time, unless this is at the beginning of the year when the government distributes blankets to them. On occasions too, when they want to make long journeys along the coast, they come aboard the steam-boats, where they are given free passage.

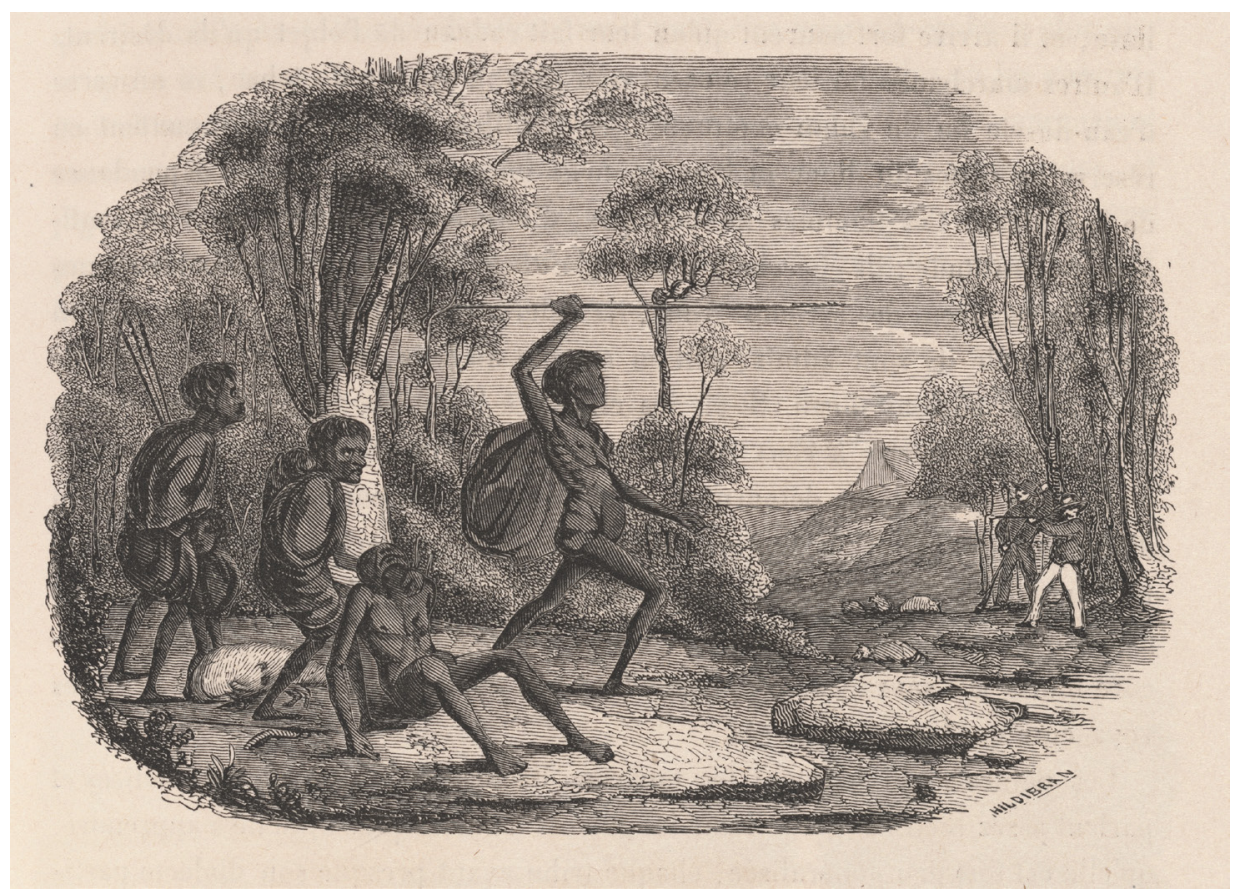

One traveller has depicted these men as tenacious and even insolent beggars, but I have never met a single black man who answers this description. They are not in the habit of annoying anyone, unless people seem to take pleasure in ogling

11 In English in the original text. 
them, which sometimes happens. How, indeed, can one prevent oneself from staring with curiosity at these men, clad in the most grotesque of costumes, be it a suit without trousers, a waist-coat without a shirt, or simply a pair of underpants. Sometimes just a kangaroo skin will serve the purpose! Soon, noticing the attention being given to them, they take advantage of it to ask for a few pence which they use to buy tobacco, and their request is always accompanied by grand salutations. They are generally quite well received in the shops, which they rarely leave without being given a little something. If they need a fish-hook, for example, they go to a hardware store, and they often obtain the object they desire as a gift. Other shop-keepers do not refuse them a little tobacco, or a glass of brandy or common rum. Charitable families put aside for them left-overs from dinner, and put them up in some part of their house. These men, it should be said, do not lack a sense of gratitude. They seek quite willingly to be of service to the people who have helped them. In this way they will help the servants chop wood, or look after fetching water.

If they are sent fishing they faithfully bring back their entire catch to those whom they regard as their masters. There are few examples of them misappropriating the slightest thing belonging to their house of adoption. On occasion people are not afraid to entrust them with rifles, and they set out to hunt game, without even having the idea of fleeing with these weapons which, for them, would be a fortune. The Aborigines of the interior, still completely savage [sauvages], have however a strong inclination for theft, if we believe the travellers who have observed them.

The natives who live around Sydney are half civilised, and speak English quite well. Their language is all the more difficult to learn because it is not at all generalised, each tribe having its own dialect which differs so much from others that tribes, situated only ten leagues from one another, cannot understand each other or communicate. As a consequence, one finds few whites who can say a few words or make themselves understood by the Indigenous people. There does exist, however, a grammar book of the language of the natives of Hunter's River [sic] and the Macquarie River, written by Mr Threlkeld, which I have looked at. I have thus got to know and memorised several words and phrases of this language, which have been useful to use on a few occasions. ${ }^{12}$

The young sportsmen of Sydney seek out the strongest and handsomest men whom they employ to beat the undergrowth when they go hunting. These men are of great help to them for they know better than the whites where game is most plentiful.

The English have perhaps still not done everything they should to elevate this barbaric race [cette race barbare] of Aborigines of New South Wales. They persist in allowing them to wander almost naked about the streets of the towns, when

12 The Reverend Lancelot Threlkeld had published An Australian Grammar comprehending the principles and natural rules of the language as spoken by the Aborigines in the vicinity of Hunter River, Lake Macquarie etc., NSW (1834). 
it would be easy to require them to dress, at least every time they come into places inhabited by Europeans. One could believe they would quickly conform to this requirement if it were imposed upon them. ${ }^{13}$ Doubtless, the charm which these people (who are not alien to the enjoyments of life and society) find in a wandering vagabond life will always present some obstacle to civilising them. Perhaps, however, more could be done than has been attempted till now. Schools had been established for the natives, where they could learn to read and write, which they did as quickly and as well as the whites. These schools have been closed, and I do not know what caused this. A project has just been adopted by the Legislative Chamber aiming to improve the lot of these men, who cannot be repelled forever, and of whom it is not impossible to soften the ways of life and to master the savage instincts [les instincts sauvages].

\section{References}

Angas, George French 1847, Savage Life and Scenes in Australia and New Zealand, 2 vols, Smith, Elder and Co, London.

Arago, Jacques 1839, Souvenirs d'un aveugle, voyage autour du monde, 4 tomes, Hortet et Ozanne, Paris.

Barrington, George 1802, The History of New South Wales, including Botany Bay and its dependencies, M Jones, London.

Delessert, Eugène 1848, Voyages dans les deux océans Atlantique et Pacifique, 1844 à 1847, Brésil, Etats-Unis, Cap de Bonne-Espérance, Nouvelle-Hollande, NouvelleZélande, Taïti, Philippines, Chine, Java, Indes Orientales, Egypte, A Franck, Paris.

Ellis, MH 1958, Lachlan Macquarie, Angus and Robertson, Sydney.

Fowles, Joseph 1848, Sydney in 1848, J Fowles, Sydney.

Freycinet, Louis de 2001, Reflections on New South Wales, 1788-1839, Hordern Press, Sydney.

Milius, Pierre 1987, Récit d'un voyage aux terres australes, Société Havraise d'Etudes Diverses, Muséum d'histoire naturelle du Havre, Le Havre.

Mitchell, Major Thomas Livingstone 1839, Three Expeditions into the Interior of Eastern Australia, 2 vols, T and W Boone, London.

13 In his Souvenirs d'un aveugle, Jacques Arago (with Louis de Freycinet's expedition) had already suggested that 'it would be wise and moral to deny entry to Sidney [sic] to those natives [naturels] who present themselves without clothes', Arago 1839, tome IV: 104. However, the question did not seem so pressing to the British authorities. In 1816 Governor Macquarie had banned 'any black native or body of natives' from entering Sydney with weapons, but had made no mention of the need for clothes; Ellis 1958: 356. 


\section{ABORIGINAL HISTORY 2013 VOL 37}

Scott, Ernest 1914, The Life of Matthew Flinders, Angus and Robertson, Sydney.

Smith, Keith Vincent 1992, King Bungaree, Kangaroo Press, Kenthurst.

Threlkeld, Reverend Lancelot 1834, An Australian Grammar comprehending the principles and natural rules of the language as spoken by the Aborigines in the vicinity of the Hunter River, Lake Macquarie etc. NSW, Stephens and Stokes, Sydney: 131 pp. 